\title{
REFLEXOS DOS PRINCÍPIOS PROCESSUAIS DO CÓDIGO DE PROCESSO CIVIL DE 2015 NA ATIVIDADE PROBATÓRIA DO PROCESSO ADMINISTRATIVO FISCAL
}

\author{
Fábio de Tarsis Gama Cordeiro*
}

RESUMO: O objetivo deste artigo é analisar os reflexos dos princípios processuais do código de processo civil (CPC/2015) na atividade probatória do processo administrativo fiscal - PAF. Utilizando-se o método científico dedutivo e como método procedimental as pesquisas bibliográfica e documental, chegou-se à conclusão de que a aplicação supletiva e subsidiária do $\mathrm{CPC} / 2015$ ao PAF é um presente do legislador ordinário a este contencioso administrativo, garantindo a sua processualização e reforçando o compromisso assumido pelo constituinte originário de consagrar e fortalecer o devido processo legal, o contraditório e a ampla defesa nesta jurisdição administrativa.

PALAVRAS-ChAVE: Código de processo civil. Princípios processuais. Processo administrativo fiscal. Aplicação supletiva e subsidiária. Compatibilidade sistêmica.

\section{REFLECTIONS OF THE PROCEDURAL PRINCIPLES OF THE CIVIL PROCESS CODE OF 2015 IN THE PROBATORY ACTIVITY OF THE FISCAL ADMINISTRATIVE PROCESS}

\begin{abstract}
The article objective is the analysis of the reflexe of the procedural principles of the code of civil procedure (CPC/2015) in the evidential activity of the administrative tax process - PAF. Using the deductive scientific method and the bibliographic and documentary research as a procedural method, it was concluded that the supplementary and subsidiary application of $\mathrm{CPC} / 2015$ to the PAF is a gift from the ordinary legislator to this administrative litigation, guaranteeing its processing and reinforcing the commitment assumed by the original constituent to enshrine and strengthen due process, contradictory and broad defense in this administrative jurisdiction.
\end{abstract}

KEYWORDS: Civil procedure code. Procedural principles. Tax administrative process. Supplementary and subsidiary application. Systemic compatibility.

\section{INTRODUÇÃO}

Estabelece o art. 15, da Lei $\mathrm{n}^{\circ}$ 13.105, de 16 de março de 2015 (CPC/2015) (BRASIL, 2015a), que, na ausência de normas que regulem processos eleitorais, trabalhistas

\footnotetext{
* Mestrando em Direito pela Faculdade CERS, especialista em Direito Processual Civil pela Faculdade CERS e Análise de Sistemas pela Universidade Federal do Pará, graduado em Direito pela Faculdade de Belém (Fabel), graduado em Ciências Navais com habilitação em Administração de Sistemas pela Escola Naval. AuditorFiscal da Receita Federal do Brasil. E-mail: ffabiogama@gmail.com.
} 
ou administrativos, as suas disposições devem ser aplicadas, supletiva e subsidiariamente, a estes processos.

Com a finalidade de conferir efetividade a referido dispositivo processual e segurança jurídica aos seus magistrados, aos servidores e, acima de tudo, aos seus jurisdicionados, o Tribunal Superior do Trabalho (TST) aprovou a Resolução TST no 203 , de 15 de março de 2016, na qual editou a Instrução Normativa TST n 39/2016 (BRASIL, 2016b), que tem por finalidade dispor sobre as normas do Código de Processo Civil de 2015 aplicáveis e inaplicáveis ao Processo do Trabalho, de forma não exaustiva.

Seguindo a prática do TST, o Tribunal Superior Eleitoral (TSE) editou a Resolução TSE $n^{\circ}$ 23.478, de 10 de maio de 2016 (BRASIL, 2016a), a qual tem por finalidade estabelecer diretrizes gerais para a aplicação da Lei $n^{\circ}$ 13.105, de 16 de março de 2015 - Novo Código de Processo Civil -, no âmbito da Justiça Eleitoral.

Contudo, as boas práticas observadas na justiça do trabalho e na justiça eleitoral não foram seguidas pelo Poder Executivo, em especial pela Administração Tributária, motivo pelo qual há um hercúleo esforço na construção jurisprudencial dos dispositivos do CPC/2015 que são compatíveis com o processo administrativo fiscal, construção essa que muitas das vezes são divergentes entre turmas e/ou unidades responsáveis pelo contencioso administrativo fiscal de primeira instância ${ }^{1}$.

Há mais de 05 anos da vigência do CPC/2015, os limites da sua aplicabilidade ao processo administrativo fiscal (PAF), em especial o federal, ainda não se encontram claramente delineados, sendo comum a apresentação de argumentos pela aplicação de institutos e normas processuais consagrados no processo civil, sem, contudo, uma análise crítica da sua compatibilidade com o microssistema processual no qual pretendem que sejam inseridas.

Entre estes institutos e normas processuais se encontram os princípios processuais consagrados no CPC/2015, os quais foram esquecidos pela doutrina especializada ${ }^{2}$ ao dispor sobre o Processo Administrativo Fiscal e que influenciam a atividade probatória desse.

\footnotetext{
${ }^{1}$ Embora existam manifestações pontuais sobre a aplicação de dispositivos do CPC/2015 no contencioso administrativo fiscal, a exemplo da orientação constante na solução de consulta interna (SCI) Cosit $n^{\circ}$ 8/2019, que dispõe sobre a possibilidade da reunião de processos para julgamento conjunto quando possuem o mesmo rito processual e são conexos, ou suspenderem o seu andamento, por prazo razoável, para as situações de ritos distintos e prejudicialidade externa. (BRASIL, 2019).

${ }^{2}$ Neste sentido, Machado Segundo (2019, p. 34-53) e Marins (2019, p. 139-199) ao traçarem os princípios do processo tributário não apresentam entre eles os princípios processuais do CPC/2015. Da mesma forma,
} 
É diante desse cenário que surge o problema de pesquisa que norteará o presente trabalho: Quais os reflexos dos princípios processuais do CPC/2015 na atividade probatória do processo administrativo fiscal? Como objetivo geral, o trabalho visa demonstrar a influência dos princípios processuais do CPC/2015 na atividade probatória do processo administrativo fiscal e como objetivo específico especificar a importância da aplicabilidade do CPC/2015 para o PAF e para a atividade probatória neste contencioso, descrevendo que a colmatação das lacunas determinada pelo legislador ordinário não pode ser realizada sem uma análise critica da norma a ser integrada com o microssistema processual lacunoso.

Utilizou-se o método científico dedutivo em uma abordagem qualitativa e como método procedimental as pesquisas bibliográfica e documental.

Em virtude de as disposições principiológicas e normativas a serem observadas na atividade integrativa do PAF já se encontrarem devidamente examinadas pela doutrina processualista civil, optou-se pelo método dedutivo, partindo-se do CPC/2015, diploma legislativo que irá emprestar a norma a ser integrada, para o Processo Administrativo Fiscal microssistema processual lacunoso no qual a norma será inserida.

Faz-se necessário observar que este trabalho não tem a audácia de exaurir o tema, mas apresentá-lo sob uma nova perspectiva, uma perspectiva na qual a obsoleta noção de vulnerabilidade entre as partes que compõe o processo administrativo fiscal deve ser abandonada em razão da sua processualização, a qual impõe a todos os sujeitos que integram a relação processual a responsabilidade pela obtenção de um resultado justo à lide tributária; embora, em um primeiro momento, essa nova perspectiva possa parecer utópica.

\section{DO PROCESSO ADMINISTRATIVO FISCAL NA ESFERA FEDERAL - LEGISLAÇÃO APLICÁVEL}

O processo administrativo fiscal (PAF), espécie do gênero processo administrativo, encontra-se assegurado constitucionalmente no direito de petição, na garantia ao devido processo legal e no direito ao contraditório e a ampla defesa.

Integra, segundo Marins (2019, p. 92), “[...] a etapa litigiosa do percurso de formalização da obrigação tributária no âmbito da Administração tributária" e se encontra disciplinado, em âmbito federal, pelo Decreto no 70.235, de 6 de março de 1972 (BRASIL, 1972); que, embora não tenha sido editado pelo Poder Legislativo, foi recepcionado com

Machado Segundo (2018, p. 455-467), ao dispor sobre os reflexos do código de processo civil de 2015 nos processos administrativos fiscais, não trouxe os princípios processuais positivados no CPC/2015. 
status de lei ordinária ${ }^{3}$, em razão da competência material esculpida no art. 22, inciso I, da Constituição da República Federativa do Brasil (CRFB) (BRASIL, 1988).

O Decreto $\mathrm{n}^{\circ}$ 70.235, de 1972 (BRASIL, 1972), traz em seu bojo não somente normas processuais a serem observadas na solução da lide tributária, mas também normas a serem observadas no decorrer do procedimento administrativo, o qual possui caráter meramente inquisitivo, procedimental e instrutório a atividade de lançamento, razão pela qual, muitas das vezes, há uma confusão ${ }^{4}$ de ambos os institutos (procedimento x processo).

A partir da vigência da Lei nº 9.784, de 29 de janeiro de 1999 (BRASIL, 1999), que regula o processo administrativo no âmbito da Administração Pública Federal, essa passou a ser aplicada ao PAF de forma subsidiaria, em decorrência do comando legislativo esculpido no seu art. 69.

Marins (2019, p. 261), ao dispor sobre as noções introdutórias do processo administrativo fiscal (PAF), leciona que a Lei ${ }^{\circ}$ 9.784/1999, a qual denominou de LGPAF, “[...] presta-se seguramente para a colmatação subsidiária de lacunas principiológicas das quais se ressente o Dec. 70.235/1972, tornando sua interpretação e aplicação mais compatíveis com o atual estágio de evolução do Processo Administrativo Fiscal”.

O Código de Processo Civil (CPC/2015) trouxe em seu bojo determinação para que, na ausência de normas que regulem processos eleitorais, trabalhistas ou administrativos, as suas disposições sejam aplicadas supletiva e subsidiariamente a esses processos e, com isto, este diploma legislativo passou a integrar, em conjunto com a LGPAF, legislação de observância obrigatória no processo administrativo fiscal, assumindo o protagonismo de norma geral do processo administrativo (gênero), do qual o processo administrativo fiscal faz parte (espécie).

\footnotetext{
3 "O Dec. 70.235/1972 foi editado como ato administrativo do Poder Executivo com fundamento no Dec.-lei 822, de 05.09.1969. A seu turno, o Dec.-lei 822/1969 foi ato dos Ministros da Marinha de Guerra, do Exército e da Aeronáutica Militar no uso de atribuições conferidas pelos AI-5 e AI-12 (respectivamente, 13.12.1968 e 31.08.1969)." (MARINS, 2019, p. 261).

${ }^{4}$ De forma exemplificativa, é possível citar a argumentação pela anulação do lançamento tributário em virtude de suposto cerceamento ao direito de defesa que possa ter ocorrido no decorrer do procedimento fiscal. Porém, o inciso LV, art. $5^{\circ}$, da CRFB, assegura o contraditório e a ampla defesa aos "litigantes, em processo [...] administrativo". Por sua vez, no processo administrativo fiscal, a fase litigiosa do procedimento é instaurada com a impugnação, consoante disposto no art. 14, do Decreto $\mathrm{n}^{\circ}$ 70.235, de 1972 (BRASIL, 1972). Razão pela qual não há que se falar em cerceamento ao direito de defesa no decorrer do procedimento fiscal. Neste sentido, Machado Segundo (2019, p. 37) afirma que a ampla defesa e o contraditório “[...] Não incide[m] sobre os meros procedimentos, os quais, não obstante, não podem ser desenvolvidos nem concluídos de modo a inviabilizar o posterior direito de defesa (como a lavratura de auto de infração desprovido de fundamentação, [...].".
} 
Embora seja possível observar a existência de duas normas gerais (LGPAF e CPC/2015) para colmatar as lacunas existentes no Decreto no 70.235, de 1972 (BRASIL, 1972), induzindo a possibilidade de uma possível antinomia de segundo grau entre ambas, em razão da observância dos critérios cronológico (CPC/2015 é mais recente que a LGPAF) e da especialidade (LGPAF é norma especial de regência do processo administrativo), o CPC/2015 afastou qualquer possibilidade de conflito entre os seus dispositivos e a LGPAF ao dispor que as suas disposições são aplicadas de forma supletiva e subsidiaria "na ausência de normas que regulem processos [...] administrativos [...]”. (BRASIL, 2015a).

Portanto, observando as delimitações estabelecidas por ambas as normas gerais, constata-se que não há conflito entre estes diplomas legislativos, os quais, nas suas funções de norma geral do processo administrativo fiscal, devem ser observadas segundo uma ordem bem delineada pelo legislador ordinário: encontrada uma lacuna no PAF, observa-se subsidiariamente as disposições da LGPAF e, persistindo a lacuna, observa-se subsidiariamente e supletivamente as disposições do CPC/2015.

Nery Junior e Nery (2018, p. 255/256) diferenciam a aplicação supletiva da aplicação subsidiária afirmando que naquela ocorre omissão absoluta (lacuna plena), enquanto nesta a omissão é relativa (lacuna parcial); porém, em ambas as soluções apresentadas pela legislação para suprimir as lacunas encontradas nos processos administrativos, deve o CPC/2015 “[...] guardar compatibilidade com o processo em que se pretende aplicá-lo".

A análise desta compatibilidade sistêmica se reveste de importância significativa à medida que afasta a aplicação de normas processuais incompatíveis com a dinâmica processual do processo administrativo fiscal e/ou com os princípios que o regem; pois, afinal, observa Didier Jr. (2020, p. 47, grifo nosso) que "O processo deve ser compreendido, estudado e estruturado tendo em vista a situação jurídica material para a qual serve de instrumento de tutela.".

Neste sentido, Marins (2019) observa que o direito processual tributário, do qual o processo administrativo fiscal faz parte, possui contornos próprios, o que o torna um processo diferenciado em razão de a própria relação jurídica tributária que dá origem a lide tributária ser dotada de particularidades e a autotutela estatal se encontrar "[...] inarredavelmente amarrada a critérios exclusivamente legais, vinculantes da atuação do agente público, e teleologicamente não pode prescindir o elemento axiológico: a realização da justiça tributária” (MARINS, 2019, p. 83-84). 
De forma exemplificativa, é possível apontar a incompatibilidade com o PAF da produção de prova testemunhal e da intimação ao patrono constituído.

Com relação a prova testemunhal, o processo administrativo fiscal é desprovido de uma audiência de instrução e julgamento na qual deva ser produzida, embora tal fato não impeça que o contribuinte leve ao conhecimento do julgador administrativo, utilizando de meios transversos ${ }^{5}$, os fatos que pretendia apresentar com a prova testemunhal.

Por sua vez, a intimação dos atos e termos processuais direcionada ao patrono constituído, muitas das vezes suscitado no contencioso administrativo fiscal com fundamento no art. $272, \S 2^{\circ}$ e $\S 5^{\circ}$, do CPC/2015, acompanhado de argumentação pela nulidade dos atos caso não efetuada a intimação consoante requerido, também não guarda compatibilidade com o contencioso administrativo fiscal, pois o Decreto $\mathrm{n}^{\circ}$ 70.235, de 1972 (BRASIL, 1972), estabelece regramento específico para as intimações realizadas pela Administração Tributária Federal, consoante o disposto no seu art. 23, caput e parágrafos, e, portanto, não se verifica omissão, seja relativa ou absoluta, razão pela qual os dispositivos do CPC/2015 que versam sobre a intimação do patrono constituído não são aplicáveis no $\mathrm{PAF}^{6}$.

\section{A IMPORTÂNCIA DA APLICABILIDADE DO CÓDIGO DE PROCESSO CIVIL (CPC/2015) NO PROCESSO ADMINISTRATIVO FISCAL}

Machado Segundo (2018, p. 455-456), ao traçar algumas notas sobre os "reflexos do código de processo civil de 2015 nos processos administrativos tributários", traz, entre os fatos relevantes para aplicação do Código de Processo Civil de 2015 ao PAF, além do caráter didático das suas disposições, o frequente desrespeito ao devido processo legal que haveria neste contencioso administrativo "[...] pelo fato de as autoridades de julgamento administrativo não contarem com um regime jurídico capaz de lhes garantir a autonomia indispensável a que tenham efetiva imparcialidade [...]”,

\footnotetext{
${ }^{5}$ Embora não seja possível a produção dessa prova no bojo da jurisdição administrativa fiscal, isso não significa que o contribuinte não possa levar ao conhecimento do julgador administrativo os fatos que entende relevantes e que possam influenciar a sua convicção. Referidos fatos podem ser apresentados por meios transversos, mediante a redução da prova oral a uma prova documentada através da lavratura de ata notarial na qual seja possível ao contribuinte, quando da sua impugnação, carrear aos autos os fatos que entende importantes para a solução do litígio.

${ }^{6}$ Neste sentido, é pacifico os precedentes do Conselho Administrativo de Recursos Fiscais (CARF), os quais se encontram devidamente sumulados na súmula CARF $\mathrm{n}^{\circ}$ 110: "No processo administrativo fiscal, é incabível a intimação dirigida ao endereço de advogado do sujeito passivo. (Vinculante, conforme Portaria ME ${ }^{\circ} 129$ de 01/04/2019, DOU de 02/04/2019)" (BRASIL, 2018c)

7 Em outra oportunidade, Machado Segundo (2019, p. 45) afirmou que o mérito das decisões dos órgãos julgadores não se encontra submetidos ao poder hierárquico.
} 
Com a devida vênia ao d. doutrinador, a autoridade tributária julgadora, na esfera federal, goza de autonomia na apreciação da prova, a qual é decorrente da sua "livre convicção", e possui o dever de imparcialidade nas suas decisões, imparcialidade essa assegurada pela própria Administração Tributária9 .

Referidas autonomia e imparcialidade da autoridade tributária julgadora, em especial das Delegacias de Julgamento da Receita Federal do Brasil- DRJ, podem ser observadas nos relatórios anuais de atividades da Secretaria da Receita Federal do Brasil referentes aos períodos de 2017 (BRASIL, 2017) e 2018 (BRASIL, 2018b), segundo os quais, das autuações fiscais questionadas administrativamente, a Administração Tributária obteve êxito integral ${ }^{10}$ tão somente em $53 \%$ e $50,7 \%{ }^{11}$ das autuações fiscais questionadas administrativamente.

Porém, embora a autoridade tributária julgadora possua autonomia na apreciação da prova e independência nas suas decisões, esse é, pela própria natureza do regime jurídico a que o contencioso administrativo se encontra submetido, limitado em face de princípios constitucionais $^{12}$ valiosos que traçam a atuação deste julgador, não podendo, à título exemplificativo, “[...] afastar a aplicação ou deixar de observar tratado, acordo internacional, lei ou decreto, sob fundamento de inconstitucionalidade" ${ }^{13}$ (BRASIL, 1972); razão pela qual, de per si, as disposições do CPC/2015 que versam sobre a arguição de inconstitucionalidade se mostram incompatíveis com o PAF, pois ao julgador administrativo carece os poderes jurisdicionais que são próprios do poder judiciário.

\footnotetext{
${ }^{8}$ Art. 29. Na apreciação da prova, a autoridade julgadora formará livremente sua convicção, podendo determinar as diligências que entender necessárias. (BRASIL, 1972).

${ }^{9}$ Art. 17. São deveres do julgador: I - exercer sua função pautado por padrões éticos, especialmente os relativos à imparcialidade, à integridade, à moralidade e ao decoro; [...] (BRASIL, 2020) e Art. 41. São deveres dos conselheiros, dentre outros previstos neste Regimento Interno: I - exercer sua função pautando-se por padrões éticos, no que diz respeito à imparcialidade, integridade, moralidade e decoro, com vistas à obtenção do respeito e da confiança da sociedade; [...] (BRASIL, 2015).

${ }^{10}$ Deve-se destacar que a informação referente ao crédito tributário "mantido parcialmente" apresentada nos relatórios referenciados inclui, além da redução parcial do crédito tributário, as decisões nas quais o colegiado decidiu tão somente pela exclusão do vínculo de responsabilidade tributária e/ou pela não manutenção das multas de ofício em sua forma qualificada e/ou agravada, fatos estes que também vão ao encontro da demonstração de autonomia e imparcialidade do julgador administrativo, à medida que tais decisões demonstram que a atuação do julgador administrativo não se encontra vinculada à vontade da Autoridade Tributária lançadora e, por consequência, dos possíveis anseios arrecadatórios do Estado.

${ }^{11}$ O gráfico do "índice de aderência ao crédito tributário" constante do relatório anual de atividades da receita federal referente ao exercício 2018, p. 51, traz tão somente as informações referentes ao $2^{\circ}$ semestre de 2018.

${ }^{12}$ Princípio da indisponibilidade do interesse público e o princípio da legalidade, dentre outros.

${ }^{13}$ Observadas as exceções constantes do art. 26-A, $\S 6^{\circ}$, do Decreto ${ }^{\circ} 70.235$, de 1972.
} 
Ao julgador administrativo de primeira instância (DRJ), ainda é defeso deixar de observar normas de efeito vinculante ${ }^{14}$, tais como pareceres normativos, notas técnicas, soluções de consulta interna e/ou súmulas do CARF com efeito vinculante, em que pese a possível argumentação, pelo contribuinte impugnante, de afronta a princípios constitucionais ou de ilegalidade destas normas e/ou súmulas vinculantes ${ }^{15}$.

Referida limitação, que não poderá ser confundida com ausência de autonomia e imparcialidade, mostra-se como um importante orientador para traçar os limites da aplicabilidade do CPC/2015 no contencioso administrativo fiscal.

Michels (2018, p. 13, grifo nosso), por sua vez, ao dispor sobre o processo administrativo fiscal, traçando os princípios constitucionais que norteiam a processualização da atividade administrativa, observa com maestria que se faz necessário:

[...] repensar a clássica formulação da doutrina pátria que define como característica basilar da atividade administrativa a autoexecutoriedade de seus atos, para fins de reconhecer que a nova Carta Magna engendra uma verdadeira processualização dessa atuação, tornando superada a ideia, vigente por décadas, de que há uma contraposição irredutível entre interesse público e interesse particular.

É neste contexto de processualização da atividade administrativa, em especial do contencioso administrativo fiscal, que a observância das normas do CPC/2015 no PAF ganha relevância, pois este lhe confere uma elevada carga principiológica eminentemente processual, a qual, quando somada as demais normas processuais, em especial a sua teoria geral das provas e disposições sobre as provas em espécie, confere ao Processo Administrativo Fiscal (PAF) os instrumentos processuais necessários para a correta solução da lide tributária e o alcance da justiça tributária.

A aplicação supletiva e subsidiária do CPC/2015 ao PAF é um presente do legislador ordinário a este contencioso administrativo, garantindo a sua processualização e reforçando o compromisso assumido pelo constituinte originário de consagrar e fortalecer o devido processo legal, o contraditório e a ampla defesa ${ }^{16}$ nesta jurisdição administrativa, trazendo

\footnotetext{
${ }^{14}$ Neste sentido, o art. 12, caput e $\S 1^{\circ}$, da Portaria RFB n ${ }^{\circ}$ 1936, de 06 de dezembro de 2018 (BRASIL, 2018a), art. 17, inciso V, da Portaria ME $\mathrm{n}^{\circ}$ 340, de 08 de outubro de 2020 (BRASIL, 2020), art. 75 do Anexo II da Portaria MF no 343, de 9 de junho de 2015 c/c art. 87, parágrafo único, incisos I e II da CRFB (BRASIL, 1988).

${ }^{15}$ Com opinião contrária, Machado Segundo (2019, p. 45) entende que a autoridade julgadora administrativa deverá desconsiderar as instruções normativas editadas pela Administração Tributária que foram observadas pela fiscalização, caso as considere contrárias à lei.

${ }^{16}$ Didier Jr. (2020, p. 95) observa que o contraditório e a ampla defesa, entre outros, "[...] são concretizações do devido processo legal e compõe o seu conteúdo mínimo".
} 
valiosos princípios processuais, além de instruí-lo com normas processuais, as quais, consoante observado por Machado Segundo (2018, p. 455-456), possuem caráter didático.

É nesta perspectiva de fortalecimento do devido processo legal, e dos princípios dele derivados, que a importância da aplicação do CPC/2015 no processo administrativo fiscal deve ser apreciada e, como consequência, faz-se necessário repensar as velhas amarras da doutrina tributarista de que o PAF é regido por uma vulnerabilidade ${ }^{17}$ do contribuinte em face da Fazenda Pública, a qual Michels (2018, p. 13) denominou de “[...] uma contraposição irredutível entre interesse público e interesse particular".

\subsection{DOS PRINCÍPIOS PROCESSUAIS DO CPC/2015 APLICÁVEIS AO PAF.}

Os princípios constituem, segundo clássica lição de Bandeira de Mello (2015, p. 54), o "[...] mandamento nuclear de um sistema, verdadeiro alicerce dele, disposição fundamental que se irradia sobre diferentes normas $[\ldots]$ ”.

Devem delinear a atuação do julgador administrativo na interpretação e na aplicação da legislação tributária, aqui entendida no seu aspecto amplo - leis, decretos, instruções normativas, pareceres normativos, soluções de consulta e outros -, bem como ao integrar a norma jurídica.

Embora a LGPAF tenha positivado princípios constitucionais, instrumentalizando o processo administrativo e, por consequência, o processo administrativo fiscal, com normas principiológicas e regras procedimentais que possibilitam segurança jurídica no exercício de direitos, não se pode esquecer que referidos princípios já se encontravam esculpidos na CRFB (BRASIL, 1988) e possuíam, embora não positivados expressamente em uma norma geral de regência do processo administrativo, eficácia normativa conferida pela força normativa da constituição e a ausência de positivação infralegal destes não era motivo para a Administração Pública e seus agentes não os observar.

\footnotetext{
${ }^{17}$ Neste sentido, leciona Marins (2019, p. 19-20) que "Essa debilidade se expressa, por consequência, no âmbito do Direito Processual Tributário, posto que ausente de disciplina própria e construído ao gosto da jurisprudência, predominantemente de natureza cível, que, atada ao raciocínio retrógrado de vulnerabilidade do Estado, coloca o contribuinte em estado de grande desvantagem, corroborando com o embate existente. A vulnerabilidade do contribuinte, que se deduz desse tríplice apoderamento do Estado e, portanto, da Fazenda Pública, leva à existência de sensível assimetria de forças entre credor-estatal e cidadão-contribuinte e fornece o fundamento para conceituar, sinteticamente, a vulnerabilidade do contribuinte como condição factual de susceptibilidade do cidadão diante da tríplice função exercida pelo Estado no âmbito da relação tributária".
} 
O CPC/2015, por sua vez, presenteou o PAF com valiosos princípios ${ }^{18}$ processuais, que, embora se encontrem localizados topologicamente no capítulo que versa das normas fundamentais do processo civil, servem "[...] de norte para a compreensão de todas as demais normas jurídicas processuais civis - é, por isso, também, uma norma de interpretação das fontes do Direito Processual e de aplicação de outras normas processuais." (DIDIER JR., 2020, p. 89, grifo nosso).

Portanto, em razão da sua função integrativa, os princípios processuais presenteados pelo CPC/2015 devem ser observados não somente quando da aplicação supletiva e subsidiária das suas normas, mas também ao compreender e aplicar a legislação processual administrativa fiscal.

\subsubsection{Do princípio da cooperação}

Positivado no art. $6^{\circ}$ do CPC/2015, Lunardi (2017, p. 84) leciona que o princípio da cooperação "[...] amplia o debate processual e que qualifica o contraditório", exigindo uma postura de diálogo entre os sujeitos da relação processual.

Trata-se de um corolário do dever de probidade, lealdade processual ${ }^{19}$ e do princípio da boa-fé en $^{20}$ os quais já se encontravam positivados ${ }^{21}$ na Lei ${ }^{\circ}$ 9.784, de 1999 (BRASIL, 1999), de observância obrigatória não somente para Administração Tributária, mas também para o contribuinte.

Todavia, embora derivado de princípios já esculpidos na norma geral de regência do processo administrativo, o princípio da cooperação confere nesse processo maior significância, pois, na lição de Nery Junior e Nelson (2018, p. 227-228, grifo nosso):

[...] as partes podem tender a certo individualismo quando da sua participação nos
atos processuais, conduzindo-se de forma a privilegiar a sua versão dos fatos em
detrimento da versão da outra parte - o que é autorizado pela famosa máxima de que
o processo civil não privilegiaria a verdade real, ao contrário do que ocorre no
processo penal. Com a explicitação da observância do dever de cooperação no CPC,
ainda que não se pretenda chegar à verdade real no processo civil, as partes, mesmo
assim, não podem privilegiar o seu interesse em desfavor da atividade estatal
judiciária.

${ }^{18} \mathrm{O}$ presente trabalho, com a finalidade de delimitar o seu escopo, optou por abordar tão somente os princípios da boa-fé objetiva, da lealdade processual e o da cooperação, em virtude da relevância que possuem na atividade probatória, porém referida delimitação não significa que outros princípios processuais do CPC/2015 não possam ser observados no processo administrativo fiscal ou que não possam influenciar a atividade probatória.

${ }^{19}$ Neste sentido, Nery Junior e Nery (2018, p. 227).

${ }^{20}$ Neste sentido, Neves (2018, p. 205), Didier Junior (2020, p. 160) e Nery Junior e Nery (2018, p. 228).

${ }^{21}$ Art. $2^{\circ}$, parágrafo único, inciso IV e art. $4^{\circ}$, inciso II. (BRASIL, 1999). 
Neste sentido, Neves (2018, p. 205) observa que a colaboração das partes com o julgador decorre naturalmente da participação destes no processo, levando aos autos não somente argumentações, mas também provas que irão auxiliar o julgador na formação de seu convencimento: “[...] Quanto mais ativa a parte na defesa de seus interesses mais colaborará com o juiz $[\ldots]$ ".."

Referido princípio se reveste de significativa importância na concretização do princípio constitucional da duração razoável do processo, atribuindo a todos os sujeitos ${ }^{22}$ da relação processual administrativa fiscal um papel ativo na rápida e justa composição do litígio administrativo e, por consequência, na obtenção da justiça tributária.

É esteado no espírito de cooperação entre as partes da relação processual e na sua relevância para que a verdade dos fatos seja alcançada, que o princípio da verdade material no contencioso administrativo fiscal - muitas vezes suscitado pelo contribuinte com o objetivo de se eximir de carrear aos autos um conjunto probatório mínimo para subsidiar a argumentação apresentada em sua impugnação, impondo ao julgador administrativo que esse "[...] assuma paternalmente a tutela da parte negligente” (DINAMARCO e LOPES, 2016, p. 65) - deve evoluir para o princípio da verdade possível, consoante será oportunamente defendido neste trabalho.

Contudo, assim como ocorre no processo civil, o princípio da cooperação se mostra de difícil aplicabilidade prática, revelando-se até mesmo utópico, lecionando Neves (2018, p. 206), de forma didática, que "[...] interpretar o dispositivo legal como previsão que exige das partes uma cooperação entre si, outorgando-lhes um dever que contraria seus próprios interesses defendidos em juízo, é utopia e tornará o dispositivo morto”.

O princípio da cooperação também ganha relevância no litígio em que se apura a presunção legal de omissão no registro de receitas ${ }^{23}$, pois o legislador ordinário, ao estabelecer uma presunção juris tantum, invertendo o ônus probatório, possibilita àquele que possui maior facilidade no encargo de produzi-la o ônus de afastar a presunção de omissão de receitas que lhe é imputado pela legislação tributária, atribuindo ao contribuinte um valioso papel no resultado justo do litígio.

É importante observar que a relevância do princípio da cooperação no contencioso administrativo fiscal não é afastar a responsabilidade de uma atuação ativa do julgador

\footnotetext{
${ }^{22}$ Autoridade tributária lançadora, autoridade tributária julgadora e contribuinte/responsável tributário.

${ }^{23}$ Decreto-Lei $n^{\circ} 1.598$, de 1977, art. 12, § $2^{\circ}$ (BRASIL, 1977) e Lei no 9.430, de 1996, art. 40 (BRASIL, 1996).
} 
administrativo, exonerando-o do seu poder-dever na busca da verdade dos fatos e na justa composição do litígio administrativo que lhe fora apresentado, mas sim aclarar que o contribuinte também se reveste de papel fundamental na obtenção de um resultado justo a lide tributária que instaurou.

\subsubsection{Do princípio da boa-fé processual e da lealdade processual}

A LGPAF já contemplava que Administração Pública e o administrado devem atuar com boa-fé, todavia, esse dever se encontra restrito tão somente aos sujeitos que integram a relação processual ${ }^{24}$.

O CPC/2015, por sua vez, elevou o dever de boa-fé ${ }^{25}$ das partes, até então positivado na LGPAF, a uma cláusula geral de boa-fé processual, a qual orienta a conduta não somente dos sujeitos processuais, mas também de todo aquele que de qualquer forma participa do processo, como, por exemplo, o perito $^{26}$ indicado na impugnação, o patrono e/ou o mandatário.

Didier Jr. (2020, p. 138) observa que “[...] trata-se de norma que impõe condutas em conformidade com a boa-fé objetivamente considerada, independentemente da existência de boas ou más intenções”.

Portanto, tratam-se o princípio da boa-fé e o princípio da lealdade processual de cláusulas gerais que devem ser observados não somente quando da atividade integrativa do CPC/2015; mas, principalmente, ao interpretar e aplicar as demais normas processuais, devendo ser observada em todo o iter processual, a iniciar quando da apresentação da impugnação a exação fiscal.

Como consequência, também é compatível com o PAF as regras de condutas conferidas no art. 77 do CPC/2015, em especial os incisos $\mathrm{I}^{27}, \mathrm{II}^{28}$ e III.

\footnotetext{
${ }^{24}$ Art. $2^{\circ}$, inciso III, e art. $4^{\circ}$, inciso II, da LGPAF. (BRASIL, 1999).

${ }^{25}$ Art. $5^{\circ}$ Aquele que de qualquer forma participa do processo deve comportar-se de acordo com a boa-fé. (BRASIL, 2015).

${ }^{26}$ Art. 16. A impugnação mencionará: [...] IV - as diligências, ou perícias que o impugnante pretenda sejam efetuadas, [...], assim como, no caso de perícia, o nome, o endereço e a qualificação profissional do seu perito. (BRASIL, 1972).

27 A LGPAF traz norma semelhante no seu art. $4^{\circ}$, inciso I, ao dispor que é dever do administrado perante a Administração expor os fatos conforme a verdade.

${ }^{28}$ Embora o Decreto ${ }^{\circ} 70.235$, de 1972 e a LGPAF não apresentem regramento semelhante, é possível, em um esforço cognitivo ao interpretar sistematicamente o art. $4^{\circ}$, inciso II, da LGPAF, que dispõe ser dever do administrado perante a Administração proceder com lealdade, deduzir a conduta do art. 77, inciso II, do CPC/2015 como ausência de lealdade.
} 
Porém, embora referidos princípios guardem compatibilidade com o processo administrativo fiscal, a sua inobservância não traz penalização (multa) em virtude da ausência de autorização legal, o que acaba por torná-los, muitas das vezes, inócuos.

Didier Jr. (2020, p. 145), ao apresentar os casos de aplicação da boa-fé objetiva da doutrina alemã, traz a proibição de venire contra factum proprium, máxima que, segundo Neves (2018, p. 209) “[...] impede que determinada pessoa exerça direito do qual é titular contrariando um comportamento anterior, já que tal conduta despreza a confiança e o dever de lealdade".

É possível observar, de forma exemplificativa, o desrespeito a lealdade e a boa-fé processual no contencioso administrativo fiscal quando o contribuinte, no decorrer do procedimento fiscal, fornece uma informação - os créditos bancários pertencem somente ao primeiro titular da conta corrente - e, posteriormente, já na impugnação ao lançamento tributário, argumenta pela sua nulidade - em virtude da existência de créditos bancários pertencentes ao segundo titular da conta corrente, haveria erro na identificação do sujeito passivo.

\subsubsection{Do princípio do ônus da impugnação específica dos fatos.}

Consubstanciado no art. 341 do CPC/2015, o princípio da impugnação específica dos fatos é compatível com o contencioso administrativo fiscal e complementa (aplicação subsidiária), didaticamente, as disposições constantes do art. 16, inciso III, do Decreto $\mathrm{n}^{\circ}$ 70.235, de 1972 (BRASIL, 1972).

De acordo com ambos os dispositivos legais, o princípio da impugnação específica dos fatos impõe ao contribuinte impugnante o ônus de se manifestar precisamente sobre as descrições do fato (plano fático) constantes do lançamento tributário e que sejam relevantes a constituição do crédito tributário em litígio e/ou ao vínculo de responsabilidade tributária, presumindo-se esses verdadeiros quando não especificamente impugnados.

Lunardi (2017, p. 452) observa que, em relação aos fatos não impugnados, há uma confissão ficta.

Todavia, a aplicabilidade de referido princípio no contencioso administrativo fiscal deve ser acompanhada de cuidados especiais (cautela), não podendo ser utilizado como motivação para se atribuir presunção de veracidade absoluta aos fatos apresentados no lançamento tributário que se encontra em litígio. 
Referida cautela decorre, em especial, da observância dos princípios constitucionais do devido processo legal e da legalidade.

É dever da autoridade tributária lançadora, quando da exigência do crédito tributário e/ou aplicação de penalidade isolada, instruir o auto de infração ou a notificação de lançamento com todos os termos, depoimentos, laudos e demais elementos de prova indispensáveis à comprovação do ilícito tributário ${ }^{29}$, devendo efetuar a subsunção do plano fático (material) ao plano jurídico (formal), motivando as exações que são imputadas pelo lançamento tributário.

Desta forma, antes de considerar presumido como verdade o conjunto fáticoprobatório carreado aos autos pela autoridade tributária lançadora, em razão de ausência de impugnação específica, é dever da autoridade tributária julgadora avaliar se os elementos carreados pela fiscalização se encontram em consonância com a infração à legislação tributária que foi imputada ao sujeito passivo, comprovando-a.

Uma vez identificado que o lançamento tributário apresenta os seus requisitos obrigatórios e se encontra devidamente acompanhado das provas que comprovam a infração à legislação tributária, poderá a autoridade tributária julgadora, observando a ausência de impugnação específica dos fatos, imputar ao impugnante os efeitos jurídicos da ausência de impugnação específica ao plano fático.

Faz-se mister observar a exceção a referido princípio positivada no art. 341, inciso III, do CPC/2015, e que também deve ser observado pelo julgador administrativo.

De acordo com o dispositivo referenciado, ainda que o impugnante não apresente impugnação especifica aos fatos apresentados pela fiscalização, estes não se presumem verdadeiros quando estiverem em contradição com a defesa, considerada em seu conjunto.

Haroldo (2017, p. 316), ao dispor sobre referenciada norma de excepcionalidade, observa que "Às vezes, um determinado fato, ao ser impugnado, tem o condão de impugnar os demais "por arrastamento"”, ou seja, ao impugnar tão somente determinados fatos, automaticamente a impugnação destes implicará a impugnação dos demais em virtude da conexão de incompatibilidade entre estes fatos.

3.1.3.1 Do princípio do ônus da impugnação específica dos fatos x da matéria não contestada

${ }^{29}$ Art. $9^{\circ}$ do Decreto ${ }^{\circ}$ 70.235, de 1972 (BRASIL, 1972). 
É necessário observar que os efeitos jurídicos do "princípio do ônus da impugnação específica dos fatos" conferido pelo CPC/2015 ao PAF não podem ser confundidos com os efeitos da "matéria não contestada" na impugnação; embora possam, em um primeiro momento, parecer conceitos semelhantes.

Estabelece o art. 17 do Decreto $\mathrm{n}^{\mathrm{o}}$ 70.235, de 1972 (BRASIL, 1972), que “considerar-se-á não impugnada a matéria que não tenha sido expressamente contestada pelo impugnante" e, portanto, em decorrência do art. 14 do diploma legislativo referenciado, o litígio, em relação a matéria não contestada, não é instaurado.

Uma vez não instaurado o litígio, não haverá apreciação do mérito e, por consequência, essa matéria constituirá a “[...] formação de autos apartados para a imediata cobrança da parte não contestada [...]"30 (BRASIL, 1972).

É possível destacar, como exemplo prático de matéria não contestada, a impugnação a auto de infração no qual foram apuradas as infrações à legislação tributária de omissão de receitas e de despesas não comprovadas (glosa de despesas), porém a impugnação contesta tão somente a infração omissão de receitas, permanecendo silente a respeito da infração despesas não comprovadas (glosa de despesas).

No exemplo apresentado, em relação as despesas não comprovadas (glosa de despesas), o litígio não foi instaurado e, portanto, a matéria não contestada será exigida mediante autos apartados e o mérito desta infração à legislação tributária não será apreciado pelo órgão colegiado.

Por seu turno, havendo o contribuinte impugnado ambas as infrações à legislação tributária que lhe foram imputadas, porém argumentando tão somente matéria de direito, permanecendo silente a respeito do plano fático e das provas que subsidiaram o lançamento tributário, presumem-se os fatos verdadeiros, consoante observância do princípio do ônus da impugnação específica dos fatos.

Neste caso, há litígio instaurado e o mérito será apreciado.

3.2 DA VERDADE POSSÍVEL NO PROCESSO ADMINISTRATIVO FISCAL: A NECESSIDADE DE UMA EVOLUÇÃO DO PRINCÍPIO DA VERDADE MATERIAL.

A aplicação supletiva dos princípios processuais e da teoria geral da prova constantes do CPC/2015 ao processo administrativo fiscal é um presente do legislador ordinário a este

$\overline{{ }^{30}{\text { Art. } 21, \S 1^{\circ} \text {, do Decreto }{ }^{\circ}}^{7} 70.235}$, de 1972 (BRASIL, 1972). 
contencioso administrativo e reforça o compromisso assumido pelo constituinte originário de consagrar e fortalecer o devido processo legal, o contraditório e a ampla defesa nesta jurisdição administrativa.

É observando estas garantias constitucionais que a busca pela verdade dos fatos se torna indissociável da atividade processual administrativa e dela não pode se afastar a Administração Pública e os seus agentes, os quais, dentro das suas limitações, tem o poderdever de persegui-la.

Porém, o processo administrativo fiscal, como atividade processual que o é, não podendo ser confundido como atividade procedimental (procedimento de fiscalização e de diligência), deve se afastar do velho paradigma consagrado na doutrina administrativista de que o processo administrativo é regido por uma incansável busca pela verdade material.

Ao dispor sobre o processo administrativo e os seus princípios, Machado Segundo (2019, p. 46/47) define o princípio da verdade material como um corolário do princípio da legalidade - do qual, destaca-se, o agente público não pode se dissociar quando do desempenho de suas atribuições -, e do poder instrutório da Administração Pública; observando Marins (2019, p. 179) e Machado Segundo (2019, p. 46), ainda, que a busca dessa verdade deve perseverar não somente na atividade processual, mas também no procedimento fiscal.

Todavia, em que pese referidos entendimentos, não se pode esquecer que é através do processo administrativo fiscal que o Poder Executivo, no exercício da sua função atípica, exerce a jurisdição, enquanto função, dos litígios tributários instaurados; portanto, trata-se o PAF de uma atividade de natureza processual ${ }^{31}$.

É com base nesta natureza processual que a verdade a ser alcançada deve ser analisada, embora as doutrinas administrativa e tributária insistam em uma dicotomia ${ }^{32}$ entre verdade material e a verdade formal, dicotomia essa já superada pela doutrina processualista civil.

\footnotetext{
${ }^{31}$ Machado Segundo (2019, p. 45) aponta a natureza jurídica controvertida do PAF, afirmando que "Poder-se-ia dizer que o julgamento administrativo, por envolver o exercício do "autocontrole", decorrente do princípio da legalidade, consistiria em algo próprio da função típica administrativa, e não jurisdicional. Preferimos, porém, entender que há aspectos nessa atividade que a aproximam da jurisdicional, razão que justifica a opção feita no texto. De uma forma ou de outra, o importante é saber que na realidade não existem divisões estanques, as quais são, na verdade, criações da mente humana para melhor compreendê-la. A existência de ornitorrincos, seres que têm penas e bicos e põe ovos, mas possuem glândulas mamárias para alimentar os filhotes, é demonstração suficiente do que se está aqui a dizer.".

32 Neste sentido, Marins (2019, p. 180) e Machado Segundo (2019, p. 53) ao disporem sobre a diferença entre verdade material e verdade formal, ainda afirmam que o processo civil é regido pela verdade formal.
} 
Marinoni e Arenhart (2019, 1. RB-2.4) lecionam que a verdade real é uma verdade utópica e, na sua essência, é inatingível, pois:

[...] a reconstrução de um fato ocorrido no passado sempre vem influenciada por aspectos subjetivos das pessoas que o assistiram, ou ainda do juiz, que há de valorar a evidência concreta. A interpretação sobre o fato - ou sobre a prova direta dele derivada - altera o seu real conteúdo, acrescentando-lhe um toque pessoal que distorce a realidade. Mais que isso, o julgador (ou o historiador, ou, enfim, quem quer que deva tentar reconstruir fatos do passado) jamais poderá excluir, terminantemente, a possibilidade de que as coisas possam ter-se passado de outra forma.

Acrescenta os autores que as provas servem para declarar a verdade a cerca de uma afirmação de fato e não do fato e observam o dever do magistrado ${ }^{33}$ em "[...] solucionar o litígio, mesmo que não esteja plenamente convencido, [...] demonstra a falsidade da tese de que o juiz, para solucionar o conflito, deve ter encontrado a verdade dos fatos." (MARINONI e ARENHART, 2019, 1. RB-7.1, grifo nosso).

Além dos aspectos subjetivos apontados por Marinoni e Arenhart (2019), a utopia na busca da verdade material também decorre das próprias limitações probatórias a que as autoridades tributárias se encontram submetidas (proteção à intimidade e à vida privada, a preservação do direito de o contribuinte não produzir prova contra si próprio, ausência de poderes jurisdicionais que são próprios do poder judiciário, dentre outros) e/ou do fato de o contribuinte em litígio se abster de carrear aos autos elementos probatórios que iriam de encontro aos seus próprios interesses, embora lhe fosse possível demonstrar os fatos conforme a verdade.

As orientações abaixo obtidas na internet (Atendimento à Fiscalização e Defesa do Contribuinte, 201-?, grifo nosso) retratam, de forma exemplificativa, a utopia em se obter a verdade real dos fatos em uma relação processual administrativo fiscal, em face da preservação do direito de o contribuinte não produzir prova contra si próprio e/ou pela inobservância do dever de cooperação:

O exposto é no sentido de que o Contador não tem obrigação por lei e NÃO DEVE apresentar outros livros, relatórios e controles que possam comprometer a empresa uma fiscalização (porque a fiscalização não tem o direito de exigi-los), pois se esses relatórios comprometem a empresa serão anexados como prova no processo contra a empresa, dificultando qualquer linha de defesa, pois os tributos levantados pelo fiscal devem ser comprovados que são devidos e deixaram de ser recolhidos, ou seja, o fiscal é que deve investigar e levantar as provas para autuar a empresa . [...] A empresa não tem obrigação de entregar ao físco

33 Também se aplica ao julgador administrativo, o qual tem o dever de solucionar o litígio que lhe foi apresentado. 
qualquer documento que possa comprometê-la, mesmo quando solicitado. $O$ objetivo da fiscalização é achar erros, falhas na documentação da empresa, anexá-las ao processo fiscal como provas para obter êxito em julgamentos tanto na esfera administrativa como judicial, pois o fiscal deve comprovar ou demonstrar evidências concretas para autuar a empresa, senão não passa de presunção, um indício de sonegação tornando a defesa com chances de êxito. Assim, cada empresa deve eleger um único profissional para se comunicar com o Fisco.

Referida dificuldade em se obter uma verdade absoluta em uma relação processual levou Neves (2018, p. 727) a afirmar que haveria a caducidade das expressões "verdade formal" e "verdade real", pois:

O melhor resultado possível do processo - que se entende mais apto a ocorrer com a
ampla produção de prova - diz respeito a qualquer processo, seja ele penal ou cível,
considerando-se que a qualidade da prestação jurisdicional será sempre o valor
supremo a ser buscado em todo o processo judicial, independentemente do direito
substancial que se está debatendo em juízo. A verdade alcançável no processo será
sempre uma só, nem material nem formal, mas processual, ou seja, aquela que
decorrer da mais ampla instrução probatória possível, o que deve ocorrer
independentemente da natureza do processo ou ainda da espécie de direito
substancial debatido.

Desta forma, embora no procedimento fiscal a busca pela verdade incontestável dos fatos (verdade material) se mostre indissociável da atividade fiscalizadora da Administração Tributária, na atividade processual, enquanto função atípica do Poder Executivo, essa necessita evoluir, de forma a acompanhar a doutrina processualista contemporânea.

\section{CONSIDERAÇÕES FINAIS}

O presente trabalho procurou analisar os reflexos dos princípios processuais do CPC/2015 no PAF sob uma perspectiva na qual a obsoleta noção de vulnerabilidade entre as partes que compõe o processo administrativo fiscal deve ser abandonada em razão da sua processualização assegurada pela constituição, a qual impõe a todos os sujeitos que integram a relação processual a responsabilidade pela obtenção de um resultado justo à lide tributária.

Apesar de no ordenamento jurídico coexistirem duas normas gerais (LGPAF e CPC/2015) para colmatar as lacunas existentes no Decreto $\mathrm{n}^{\mathrm{o}} 70.235$, de 1972, o CPC/2015 afastou qualquer possibilidade de conflito entre os seus dispositivos e a LGPAF ao dispor que as suas disposições são aplicadas de forma supletiva e subsidiaria somente quando identificada uma lacuna neste microssistema processual.

Embora o códex processual civil determine a sua aplicação nos processos administrativos e, por consequência, no processo administrativo fiscal, a aplicabilidade das suas normas extrapola a simples constatação de uma lacuna neste processo. Faz-se necessário 
perquirir se a norma processual que se pretende adequar ao processo administrativo fiscal é compatível com esse microssistema processual, em virtude das suas peculiaridades, da sua dinâmica processual e das limitações ao poder instrutório e decisório que são impostos a autoridade tributária julgadora pelo regime jurídico administrativo que este se encontra inserido.

A aplicação do CPC/2015 é um presente do legislador ordinário a este contencioso administrativo, garantindo a sua processualização e reforçando o compromisso assumido pelo constituinte originário de consagrar e fortalecer o devido processo legal, o contraditório e a ampla defesa nesta jurisdição administrativa, trazendo valiosos princípios processuais e uma teoria geral da prova até então ausente na Lei $n^{\circ}$ 9.784, de 1999 (BRASIL, 1999), e no Decreto $\mathrm{n}^{\circ}$ 70.235, de 1972 (BRASIL, 1972).

É nesta perspectiva que a importância da aplicação do CPC/2015 no processo administrativo fiscal e, por consequência, na sua atividade probatória, deve ser apreciada.

Os princípios processuais, em razão da sua função integrativa, e a teoria geral da prova presenteados ao PAF pelo CPC/2015 fortaleceram e ampliaram o devido processo legal e os princípios dele derivados, funcionando as suas normas, muitas das vezes, não somente para colmatar lacunas, mas como orientador na atividade interpretativa das disposições da legislação processual administrativa fiscal.

É esteado na natureza processual do PAF, nos princípios e nas regras processuais presenteados pelo CPC/2015 e na caducidade das expressões "verdade formal" e "verdade real" que a verdade dos fatos a ser alcançada no processo administrativo fiscal necessita evoluir da utópica verdade material para a verdade possível, de forma a acompanhar a doutrina processualista contemporânea.

\section{REFERÊNCIAS}

ATENDIMENTO à Fiscalização e Defesa do Contribuinte, 201-? Disponivel em: http://www.portaldeauditoria.com.br/tematica/defesacontr_atendimentoafiscalizacaoedefesad ocontribuinte.htm. Acesso em: 11 abr. 2021.

BANDEIRA DE MELLO, Celso Antônio. Curso de direito administrativo. 32. ed. rev. e atual. São Paulo: Malheiros Editores Ltda, 2015.

BRASIL. Decreto $\mathbf{n}^{\mathbf{0}} \mathbf{7 0 . 2 3 5}$, de 6 de março de 1972. Dispõe sobre o processo administrativo fiscal, e dá outras providências, 1972. Disponivel em: http://www.planalto.gov.br/ccivil_03/decreto/D70235cons.htm. Acesso em: 07 abr. 2021. 
BRASIL. Decreto-Lei $\mathbf{n}^{\mathbf{0}}$ 1.598, de 26 de dezembro de 1977. Altera a legislação do imposto sobre a renda, 1977. Disponivel em: http://www.planalto.gov.br/ccivil_03/decretolei/del1598.htm. Acesso em: 09 abr. 2021.

BRASIL. Constituição da República Federativa do Brasil de 1988. Constituição, 1988. Disponivel em: http://www.planalto.gov.br/ccivil_03/constituicao/constituicao.htm. Acesso em: 07 abr. 2021.

BRASIL. Lei no 9.430, de 27 de dezembro de 1996. Dispõe sobre a legislação tributária federal, as contribuições para a seguridade social, o processo administrativo de consulta e dá outras providências, 1996. Disponivel em: http://www.planalto.gov.br/ccivil_03/leis/19430.htm. Acesso em: 09 abr. 2021.

BRASIL. Lei no 9.784, de 29 de janeiro de 1999. Regula o processo administrativo no âmbito da Administração Pública Federal, 1999. Disponivel em: http://www.planalto.gov.br/ccivil_03/leis/19784.htm. Acesso em: 10 abr. 2021.

BRASIL. Lei no 13.105, de 16 de março de 2015. Código de Processo Civil, 2015. Disponivel em: http://www.planalto.gov.br/ccivil_03/_ato2015-2018/2015/lei/113105.htm. Acesso em: 07 abr. 2021.

BRASIL. Ministério da Economia. Portaria MF no 343/2015. Aprova o Regimento Interno do Conselho Administrativo de Recursos Fiscais (CARF) e dá outras providências, 09 jun. 2015. Disponivel em:

http://normas.receita.fazenda.gov.br/sijut2consulta/link.action?idAto=65007\&visao. Acesso em: 10 abr. 2021.

BRASIL. Tribunal Superior Eleitoral. Resolução TSE $\mathbf{n}^{0}$ 23.478, de 10 de maio de 2016. Estabelece diretrizes gerais para a aplicação da Lei no 13.105 , de 16 de março de 2015 - Novo Código de Processo Civil -, no âmbito da Justiça Eleitoral, 2016. Disponivel em:

https://www.tse.jus.br/legislacao/codigo-eleitoral/normas-editadas-pelo-tse/resolucao-no-23478-de-10-de-maio-de-2016-2013-brasilia-2013-df. Acesso em: 08 abr. 2021.

BRASIL. Tribunal Superior do Trabalho. Resolução TST no 203/2016. Edita a Instrução Normativa $\mathrm{n}^{\circ} 39$, que dispõe sobre as normas do Código de Processo Civil de 2015 aplicáveis e inaplicáveis ao Processo do Trabalho, de forma não exaustiva., 15 mar. 2016. Disponivel em: http://www.tst.jus.br/documents/10157/429ac88e-9b78-41e5-ae28-2a5f8a27f1fe. Acesso em: 10 abr. 2021.

BRASIL. Ministério da Economia. Secretaria Especial da Receita Federal do Brasil.

Relatório Anual de Atividades da Receita Federal, 2017. Disponivel em:

http://receita.economia.gov.br/publicacoes/relatorio-anual-de-atividades/ra_2017_versaoweb.pdf. Acesso em: 11 abr. 2021.

BRASIL. Ministério da Economia. Secretaria Especial da Receita Federal do Brasil. Portaria RFB n' 1936, 06 de dezembro de 2018. Dispõe sobre Consulta Interna, consulta à Procuradoria-Geral da Fazenda Nacional, solução de conflitos de competência entre unidades descentralizadas, revisão de atos normativos elaborados pela Secretaria da Receita Federal do 
Brasil e sobre a realização, 06 dez. 2018. Disponivel em: http://normas.receita.fazenda.gov.br/sijut2consulta/link.action?idAto $=97482 \&$ visao $=$ compilad o. Acesso em: 10 abr. 2021.

BRASIL. Ministério da Economia. Secretaria Especial da Receita Federal do Brasil.

Relatório Anual de Atividades da Receita Federal, 2018. Disponivel em:

http://receita.economia.gov.br/publicacoes/relatorio-anual-de-atividades/ra_2018_-1.pdf/view. Acesso em: 11 abr. 2021.

BRASIL. Ministério da Economia. Conselho Administrativo de Recursos Fiscais (CARF).

Súmula CARF no 110. No processo administrativo fiscal, é incabível a intimação dirigida ao endereço de advogado do sujeito passivo, 03 set. 2018. Disponivel em:

http://idg.carf.fazenda.gov.br/noticias/2019/arquivos-e-imagens/portaria-me-129-

sumulas_efeito-vinculante.pdf. Acesso em: 10 abr. 2021.

BRASIL. Ministério da Economia. Secretaria Especial da Receita Federal do Brasil. Solução de Consulta Interna COSIT $\mathbf{n}^{\mathbf{0}} \mathbf{8}$, de 06 de novembro de 2019. PROCESSOS CONEXOS. PREJUDICIALIDADE. RITOS. REUNIÃO DE PROCESSOS. SUSPENSÃO DE PROCESSOS, 06 nov. 2019. Disponivel em:

http://normas.receita.fazenda.gov.br/sijut2consulta/link.action?visao=anotado\&idAto $=104874$ . Acesso em: 08 abr. 2021.

BRASIL. Ministério da Economia. Portaria ME no 340/2020. Disciplina a constituição das Turmas e o funcionamento das Delegacias de Julgamento da Secretaria Especial da Receita Federal do Brasil - DRJs, e regulamenta o contencioso administrativo fiscal de pequeno valor, 08 out. 2020. Disponivel em:

http://normas.receita.fazenda.gov.br/sijut2consulta/link.action?visao=anotado\&idAto $=113041$ \#2193215. Acesso em: 11 abr. 2021.

DIDIER JR., Fredie. Curso de direito processual civil: introdução ao direito processual civil, parte geral e processo de conhecimento. 22. ed. rev. ampl. e atual. Salvador: Ed. JusPodivm, 2020. v. 1.

DINAMARCO, Cândido Rangel; LOPES, Bruno Vasconcelos Carrilho. Teoria geral do novo processo civil. $2^{\text {a }}$. ed. rev. atual e ampl. São Paulo: Malheiros, 2016.

HAROLDO, Lourenço. Processo civil: sistematizado. $2^{\text {a }}$. ed. ref. e atual. São Paulo: Forense, 2017.

LUNARDI, Fabrício Castagna. Curso de direito processual civil. $2^{a}$. ed. rev. atual. e ampl. São Paulo: Saraiva, 2017.

MACHADO SEGUNDO, Hugo de Brito. Reflexos do Código de Processo Civil de 2015 nos Processos Administrativos Tributários. In: CARDOSO, A. M., et al. Processo

Administrativo Tributário. Belo Horizonte: Editora D’Plácito, 2018. p. 455-467.

MACHADO SEGUNDO, Hugo de Brito. Processo tributário. 11. ed. rev. atual. e ampl. São Paulo: Atlas, 2019. 
MARINONI, Luiz Guilherme; ARENHART, Sérgio Luiz. Prova e convicção. $3^{\text {a }}$ ed. em ebook baseado na 5. ed. impressa. São Paulo: Thomson Reuters Brasil, 2019.

MARINS, James. Direito processual tributário brasileiro: administrativo e judicial. 12. ed. São Paulo: Thomson Reuters Brasil, 2019.

MICHELS, Gilson Wessler. Processo administrativo fiscal: litigância tributária no contencioso administrativo. São Paulo (SP): Cenofisco, 2018.

NERY JUNIOR, Nelson; NERY, Rosa Maria de Andrade. Código de Processo Civil comentado. 17. ed. rev. atual. e ampl. São Paulo: Thomson Reuters Brasil, 2018.

NEVES, Daniel Amorim Assumpção. Manual de direito processual civil: Volume único. 10. ed. rev. ampl. e atual. Salvador: Ed. JusPodivm, 2018. 